\begin{tabular}{lrr}
\hline Volume 21 & Nomor 1, Januari 2020 & Halaman 10-18 \\
URL: https://jurnal.unej.ac.id/index.php/SEMIOTIKA/index & E-ISSN: 2599-3429 & P-ISSN: 1411-5948 \\
\hline
\end{tabular}

\title{
THE SPIRIT OF FREEDOM AGAINST DEHUMANIZATION IN FREDERICK DOUGLASS' THE NARRATIVE LIFE OF FREDERICK DOUGLASS, AN AMERICAN SLAVE
}

\author{
SEMANGAT KEBEBASAN MENENTANG DEHUMANISASI DALAM NOVEL \\ THE NARRATIVE LIFE OF FREDERICK DOUGLASS, AN AMERICAN SLAVE \\ KARYA FREDERICK DOUGLASS
}

\author{
Erna Cahyawati $^{{ }^{*}}$ \\ ${ }^{1}$ Faculty of Humanities, Universitas Jember \\ *Corresponding Author: ecahyawati@gmail.com \\ Informasi Artikel:
}

Dikirim: 20/1/2020; Direvisi: 25/1/2020; Diterima: 29/1/2020

\begin{abstract}
American romanticism is a literary movement in the 19th century that upholds individualism, and freedom from all forms of confinement of convention, oppression or tyranny. This study focuses on abolitionism or the anti-slavery movement found in Frederick Douglass's autobiographical novel entitled The Narrative Life of Frederick Douglass, An American Slave. This study explores American romantic literature's characteristics in the book by capturing the dehumanization experienced by black American slaves and their spirit of resistance to the white oppression. The method used is the inductive method and descriptive method. The results showed that black people could gain confidence in striving for equality and freedom from white oppression by learning to read and write.
\end{abstract}

Keywords: romanticism, dehumanization, the spirit of freedom, slavery

Abstrak

Romanticisme Amerika adalah aliran sastra Amerika pada abad 19 yang menjunjung tinggi individualisme, dan kebebasan dari segala bentuk kungkungan konvensi, opresi atau tirani. Kajian ini berfokus pada abolisionisme atau gerakan anti perbudakan yang terlihat kuat dalam novel autobiografi karya Frederick Douglass yang berjudul The Narrative Life of Frederick Douglass, An American Slave. Studi ini bertujuan untuk mempelajari karakteristik sastra romantik Amerika yang terlihat dalam novel dengan memotret dehumanisasi yang dialami oleh budak kulit hitam Amerika dan semangat perlawanan mereka terhadap penindasan kaum kulit putih. Metode yang digunakan adalah metode induktif dan metode deskriptif. Hasil penelitian menunjukkan bahwa dengan belajar membaca dan menulis, orang kulit hitam bisa memperoleh kepercayaan diri dalam mengupayakan kesetaraan dan kebebasan dari penindasan kaum kulit putih.

Kata kunci: aliran romantic, dehumanisasi, semangat kebebasan, perbudakan 


\section{INTRODUCTION}

The influence of Romanticism in literature started from nineteenth century when France revolution of 1789 proclaimed the liberty, fraternity, and equality. It affected a man named victor Hugo to exclaim "liberalism in literature" to free the artists and writers from the restraints of Classicism. Then, the notion spread to Germany, England, and finally to America. In America, it happened during 1850-1855 and referred as the "American Renaisance (Frenz, 1954:395). In America, romanticism became connected to Utopian ideas about the idea to establish ideal society. Romantic spirit of reform also raise feminism and abolitionism. Just as the insistence on rational, formal, and conventional subject matter that had typified classicism was reversed, the authoritarian regimes that had encouraged and sustained classicism in the arts were inevitably subjected to revolutions (Padduck, 2000:168). In other words american romanticism as a movement in american literature that is characterized by reliance on the imagination, individualism, freedom of convention, and freedom of the oppression of tyranny (Clark, 1975:50).

Abolitionism is one of the romantic themes and moods that some writers concern. Abolitionism is "a social movement and ideology aimed at the prohibition of slave trade, slavery, and other forms of coerced labor. It does not give slaveholders access to the bodies and labor of enslaved as chattel (personal) property. It advocates the abolitionism of slavery. Many of the libertarian and abolitionis of the late 18th and early 19th centuries were engendered by the romantic philosophy - the desire to be free of tyranny, oppression and dehumanization. It has new emphasis on the rights and dignity of the individual (Lipset, 1995:4).

Abolitionism that provokes the spirit of anti slavery sentiment is clearly seen in Narrative of the Life of Frederick Douglass, an American Slave (NLFDAAS) (Douglass, 1881). The story opposes dehumanization and claims for the freedom of the slaves. Dehumanization refers to any acts of degrading or depriving human quality, like the act of oppression, detention, slavery, etc. Thus, freedom from dehumanization means the condition of being free from any acts of degrading/ depriving human qualities, or an exemption from unpleasant or erroneous condition caused by slavery, detention and oppression. It voices out the desire of being free from the evil of slavery.

The Narrative of The Life of Frederick Douglass, An American Slave is Douglass' autobiography (1881) that depicts his various life experiences related to dehumanization of the white masters upon the black slaves. The book also tells that using the strong spirit of freedom, the blacks revolt to escape from slavery.

Discussing the narrative is very interesting because the story is considered to be a source for the truth abolitionism. The writer of the book, Douglass, possessed the generous force of conviction through his real life's experience as a slave. He spent most of his life enslaved and therefore he had more insight into the realities of slavery. As a result, the story is very alive since it reflects the writer's real life experiences.

The study concentrates on abolitionism or anti slavery idea as one of the characteristics of romanticism found in Frederick Douglass's Narrative of The Life of Frederick Douglass, An American Slave. Here, the study tries to reveal how the black people suffer from dehumanization, and with their spirit of freedom how they fight against slavery. 
Hopefully, the study is expected to contribute to the development of literary discussion concerning abolitionism as one of the theme of American Romantic literature. Last but not least, since literature is representation of reality, the study can provide inspiration for anti slavery sentiment and give a valuable reflection to all human races that all men are created equal and racism should be banished.

\section{METHOD}

Document, books, diaries, newspaper and magazine, or even web pages and internet, can be treated as a source of (Denscombe, 2007:227). In this research, the analysis uses inductive method. Inductive can be seen as a method that is taken from the specific one to the general form. In simple way, it is a movement thought that is from particular idea to general idea. In this case, the fact is the data that are represented by the novel. Since this research also using descriptive method, this research is conducted through some steps to answer each of the research question. First, to answer the first research the study tries to reveal how the black people suffer from dehumanization, secondly how they fight against slavery with their spirit of freedom.

\section{DISCUSSION}

This part discusses dehumanization of slavery and the blacks' spirit of freedom. The dark side refers to the dehumanization suffered by the slaves that includes dehumanization on children and women, the lack of basic needs, physical abuses, the ban of getting education, working exploitation, no freedom of speech and slaves treated as property. The inhuman treatments cause the feeling of slaves' depression and hatred. The dehumanization that happens upon Douglass and the other black slaves encourages them to escape from the slavery. The condition motivates the rise of spirit of freedom that includes, the awareness of the meaning the real freedom, the longing for freedom reflected in the slave song, learning to read or write as an important step to freedom, and the intention and effort to escape from slavery.

\section{Dehumanization Toward Slave}

The dehumanization that is discussed refers to both physical and psychological dehumanization.

\section{Dehumanization on Children and Woman}

In this autobiographical novel, Douglass wants to show to all people that slavery is a form of evil dehumanization. The blacks are enslaved and regarded as persons without legal rights which the whites have to respect. He is irritated seeing the slaveholders' treatment toward slaves especially women and children is depriving human quality. The slave women are separated from her children since the children are at very early age. Slavery indeed seizes children's right to live with their mother. The women are sent and hired to work in other farms, while their children are placed under the care of an old woman. In this case, the mothers have to walk for long distance to meet their children at night. If they are late to come to the work in the next morning, their master then will whip them. 
In relation with the separation between the mother and the children, in the novel Douglass shows his annoyance seeing that slavery has cut the bond between him as a child and his mother so he never feels how to be maternally loved. He doesn't have emotional feeling toward his mother and often sees her as a stranger. When his mother dies he doesn't feel anything as he says, "I receive the tidings of her death with much the same emotions I should have probably felt at the death of a stranger" (NLFDAAS:23).

In the novel, Douglass also expresses his sadness knowing that the cut of emotional ties with the children is not the only suffering that the mothers have. The women are the helpless victims of their white master's lusts as well. They are forced to fulfill their master's sexual desire. Instead of being responsible for the babies born, the masters often sell them and regarded as slaves too. The slaveholders also have cunningly established a law to design the mulattos (the children of slave women and the white masters) to follow the condition of their mothers as well as to avoid themselves from becoming their fathers. The children become the new generation of slaves although their fathers were white.

Here, when people have right of freedom from God since they were born, children of slave women do not. They have already become slaves since they were born. Their fates are more miserable when their white mistresses mistreat them, because they represent their husband's infidelity. They also get inhumane treatment from their own fathers who do not only sell them off but also often whip them.

\section{The Lack of Basic Needs}

The food and clothes are really insufficient for the black slaves in the plantation. Without enough food, they still have to work hard. If not, the overseers will whip them. The novel also tells that in childhood, Douglass does not only suffer from hunger but also severe cold. To protect himself he has to steal a corn bag so that he can have warm sleeping on the cold. He doesn't have stockings, jacket, trousers, but only a coarse tow linen shirt, which reaches only to his knees. It seems that his master, Mr. Hugh Auld, does not give his slaves, even a young slave, proper clothes and place to protect them from the cold winter.

\section{Physical Abuses}

In the autobiographical novel, Douglass tells that he frequently witnessed slaves tortured and whipped just like animals. Here, thinking that whipping slaves a duty to make the slaves obey him, a cruel overseer often whips the slaves who ignore his commands. The barbaric treatment of the overseer is also experienced by Douglass himself. He says, "Mr. Covey gave me a very severe whipping, cutting my back, causing the blood to run, and raising ridges on my flesh as large as my little finger" (NLFDAAS:71). He further explains, "When he whipped, he seemed to do so from a sense of duty, and feared no consequences (NLFDAAS:39).

Even the white's action to kill a slave is not treated as a crime. It is acceptable as a form of punishment of the slave disobedience. The whites are allowed to kill a slave because they think that letting a slave doing mistakes can endanger the white's life. Douglass says, "Their backs had been made familiar with the bloodily lash, so that they had become callous;" (NLFDAAS: 60). As a consequence of this terrifying condition, all slaves, both males and females, are at the utmost dread and horror. 


\section{The Ban of Getting Education}

The prohibition to get education for the Black is clearly seen in the novel when in Baltimore Mr. Hugh Auld forbids Douglass to learn reading and writing. He says that ability to read will make a slave longing for freedom. The happy slave is an illiterate and ignorant slave. Mr. Auld forbids Mrs. Auld to teach Douglass reading. "Mr. Auld found out what was going on, and at once forbade Mrs. Auld to instruct me further" (NLFDAAS:54).

The ban of getting education is included into psychological abuses. The white prohibits their slaves to learn reading and writing so that they will not realize that the practice of slavery opposes their human right.

\section{No freedom of Speech}

Through his work, Douglass shows that the slaves do not freedom of speech. They have to tell that their master is the best man and the kindest; although, in fact, their master is very cruel. The slaves will be punished if they tell the truth about their masters.

"Well, does colonel treat you well?"

"No, sir," was the ready reply.

"What, does he work you too hard?"

"Yes, sir."

"Well, don't he give you enough to eat?"

"Yes, sir, he gives me enough, such as it is. (NLFDAAS:35).

Not a long time then, the slave is sold to a Georgia trader; he is separated from his family. This showed that the slaveholders oppress the freedom of saying the truth because they are worried that the truth can spoil their good names. The slaveholders are cruel but they do not want to be regarded as cruel men.

\section{Working exploitation}

Mr. Covey exploits his slaves to work all day in whatever condition of the slaves and the weather is. It is seen in quotation below:

We were worked in all weathers. It was never too hot or too cold; it could never rain, blow, hail, or snow, too hard for us to work in the field. Work, work, work, was scarcely more the order of the day than of the night. (NLFDAAS:75).

The act of Mr. Covey is very strict, he does not care about the other suffer, but he does whatever he wants. The first six months, Douglass stays with Mr. Covey. He works very hard, from early in the morning until late in the night. Moreover, he has to work in all the weathers. These show very clearly that Mr. Covey is very inhumane person. He does not give chance for the main character or other slaves to rest even one minute. He controls everything, even the mealtime. He often give them less than five minutes

Next, Douglass real experiences being exploited in working are shown clearly in this story. Master Hugh takes Douglass as a caulker in Mr. Gardner's employment. Douglass has to work and give his wages every week to Master Hugh. He brings six until seven dollars and 
sometimes nine dollars a week. Sometimes the master gives him six cents. The following quotation shows how greedy the master is when he sees Douglass wages.

When I carried to him weekly wages, he would after counting the money, look me in the face with a robber like fierceness, and ask "is this all?" He was satisfied with nothing less than the last cent (NLFDAAS:106).

The slave has to work hard and earn money not for his better life but for the masters' welfare. It is very ironical that the master enjoys the salary that comes from work he never does. On the other hand, the slave gets nothing for his own hardworking.

\section{Slaves Treated as Property}

After Captain Anthony dies, Douglass returns to Tabot County to be evaluated for the division of the property. Douglass, then, is sent back to Baltimore two years later, Mr. Hugh Auld has falling out with his brother, Thomas auld, and he is sent back to live with his master. "I was immediately sent for, to be valued with the other property" (NLFDAAS:59). Douglass and other slaves who are treated as a property is the same with the dehumanization toward slaves. It is because they are considered not as humans but as something that can be moved easily without caring how old they are. Douglass is often moved since he was a child. The slaves are separated from their family and friends that they loved as they are shared. Therefore, we consider this white's treatment as the dehumanization upon their slaves.

This dehumanization abuses Douglass' physic and psychology. Physically, since a child little Douglass has to be moved to another place without caring his health and strength. Psychologically, his movement makes him to be separated from his family. Douglass lost the affection of his mother and the entire family since he was little child.

The above is the explanation of the practices of dehumanization toward American Black slaves that is seen in the narrative of Frederick Douglass. The practices encourage the spirit of freedom of Frederick Douglass and other slaves.

\section{The Motivation and Spirit of Freedom}

The dehumanization suffered by the Blacks as it is discussed above causes the emergence of the spirit of freedom from slavery. The spirit of freedom is explained below.

\section{The Longing for Freedom Reflected in the Slave Song}

The desire to be free is reflected in the song. The words in the song show that the slaves spiritually want to be free physically. The song is slaves' expression of their deepest sorrow. They are longing for freedom.

"I am going away to the Great House Farm!

"O,yea! O, yea! O ” (NLFDAAS:31).

Douglass admits that by listening the song, his feeling of hatred for his enslaved condition arose. This encourages his spirit to get his freedom. "Every tone was a testimony against slavery, and a prayer to God for deliverance from chains" (NLFDAAS:31). 


\section{The Awareness to the Real Meaning of Freedom}

The strict working hour, the oppression by the white, the lack of basic needs make the desire in gaining freedom emerge among the slaves. Worrying to the slave's insurrection, every year between Christmas and New Year, the slaveholders gives holiday to their slaves. The slaves are free to do anything for their fun, like visiting the family, hunting, or doing sport during the six days holiday.

In that occasion, slaveholders encourage the slaves to enjoy themselves fully, and to have as much fun and as much alcohol as they can handle. Douglass sees this as the slaveholders scheme to keep the slaves at bay. They want to let the slaves experience the accesses of the freedom so that the notion of freedom itself will be disgusting for them. It is explained in the following quotation

Thus, when the slave asks for virtuous freedom, the cunning slaveholders, knowing his ignorance, cheats him with a dose of vicious dissipation artfully labeled with the name of liberty. The most of us used to drink it down ant the result was just might be supposed: many of us were led to think that there was little to choose between liberty and slavery (NLFDAAS:85).

In his work, Douglass shows that when he works for Mr. Covey, the cruelest master he has ever had he begins to aware to the real meaning of freedom for his race. He tries to make people recognize to the white's trick. Holiday is only artificial and contemporary freedom that is created by the white to cheat the slaves. They build slaves wrong perception that the freedom is always come to them every the end of the year in the form of holiday. When the holiday ends, the freedom also ends, and the people come back to the severe slavery. It is not the real freedom the people want. Douglass encourages his Black - friends to pursue the real freedom for their life that is the freedom from slavery. It is the true freedoms that really can free people completely from the evil of slavery in their life.

\section{Learning to Read or Write as an Important Step to Freedom}

Douglass' moving to Baltimore becomes an important step for him to free from the slavery because there he first learns to read. What Mr. Auld tries to explain is only encouraging Douglass to learn how to read and to write. In twelve years - old, Douglass reads the Columbian Orator and Sheridan's writing. From these books, he realizes what himself and his race experience that they are slaved by the whites. The practice of the slavery abuses the right and the liberty of his race.

He tells it to his white boy - friends so that he wants to be as free as the white. "I wish I could be as free as they would be when they got to be a man, but I am a slave for life! Have not I as good a right to be free as you have?" (NLFDAAS:54). His statement seems that he realizes that being a slave will be suffer forever. Learning to read is an important step for Douglass to freedom.

At the time, Douglass finally succeeds in reading and writing, he teaches his fellow friends. He thinks that if his friends can write and read, they can escape from the slavery. He spends his times to teach his fellow-slaves, especially on Sundays. He devotes all the times that he has in teaching. Soon they can learn to read by themselves. Although it is a little 
opportunity for them, but this is the first important point to step of their freedom in the future. It is seen in the quotation below:

I succeeded in creating in them a strong desire to learn to read. This desire soon sprang up in the others also. They very soon mustered up some old spelling-books, and nothing would do but that I must keep a Sabbath school. I agreed to do so, and accordingly devoted my Sundays to teaching these my loved fellow-slaves how to read. Neither of them knew his letters when I went there. Some of the slaves of the neighboring farms found what was going on, and also availed themselves of this little opportunity to learn to read. (NLFDAAS:89)

Douglass tries to transmit his spirit of freedom by teaching people to read and write. Douglass hopes that they can get many information that can inspire and encourage them to get freedom. Through teaching, he is also convinced that he can influence people to follow is spirit of freedom.

\section{The Intention and Efforts to Escape from Slavery}

Life as slave is full of misery. This happened to Douglass. He has to work hard, live without enough food and clothes. His master whips him very often. He is treated like an animal. This situation stimulates his intention to gain freedom. He feels that his spirit of being a free man has risen. He does not want to be a slave for his whole life.

It was glorious resurrection, from the tomb of slavery, to the heaven of freedom. My long-crushed spirit rose, cowardice departed, bold defiance took it place; and I now resolved that, however long I might remain a slave in form, the day had passed forever when I could be a slave in fact (NLFDAAS:83).

Douglass's intention to be free motivates him to get freedom for the slaves. Douglass realized that he couldn't get freedom alone. He needs some friends. He tries to convince his friends to the importance of being a free man. He feels that slavery is inhumane. He devises a plan to escape from the farm and to get freedom.

But I was not willing to cherish this determination alone. My fellow-slaves were dear to me. I was anxious to have them participate with me in this, my life-giving determination. I therefore, though with great prudence, commenced early to ascertain their views and feelings inregard to their condition, and to imbue their minds with thoughts of freedom. I bent myself to devising ways and means for our escape, and meanwhile strove, on all fitting occasions to impress them with the gross fraud and inhumanity of slavery (NLFDAAS:91).

Finally, Douglass and his friends agree to escape by canoe on Saturday night previous to Esther holiday to Maryland. They choose the water road because it is safer than the land rote.

However, their effort to escape fails. Before they do their plan they have been already betrayed. Douglass, Henry and John are put in jail. This failure makes Douglass despair. He feels that the possibility of freedom is gone. His spirit to get freedom decreases 
This feeling is last for many days until Captain Auld comes to take him out and then sends him to his brother Hugh in Baltimore. His spirit of freedom revives in Baltimore.

The failure of Douglass first attempt to escape doesn't stop the burning of his spirit to try his next escape. His desire to be free revives even stronger. Then, he prepares a neat plan for his liberty. To avoid suspicion, he tries to make his master happy and satisfied by bringing him eight and nine dollars of his wages every weekend.

Finally, he leaves secretly from New York on September 1838. The escape is the time between life and death for Douglass. Then, he succeeds in reaching and gaining his freedom. He feels like one who escapes from a hungry lion and the tortures of slavery. However, he then feels very worried having no friends, no money, no shelter, and no food in the new town. He also often feels in a great danger worrying to be pursued by men hunter. Few days in New York, Mr. Ruggles, an abolitionist, helps him and takes Douglass kindly to his boarding houses at the corner of church and Less Penard streets. Soon, he advices Douglass to go to New Bradford since it is still unsafe for him remaining in New York. Douglass and his wife finally are able to settle in New Bradford, Massachusetts. He finds work there and eventually he becomes a key speaker for the abolition movement.

\section{CONCLUSION}

Abolitionism is romanticism idea that is reflected in the narrative. It refers to the motivation and spirit of freedom from dehumanization on slavery. It is told that the dehumanization on slavery has brought much suffering to all of the blacks. Because of the misery, the slaves have high motivation and spirit to escape from the slavery and to gain their freedom.

Douglass, as the main character in the narrative represents a person who has strong self-trust. It starts when he is able to read and write. By reading he get knowledge outside that the slavery opposes the black human right. He believes with the truth that human being is created equal. With his strong self-trust his struggle to realize what he thinks true, the freedom for his race. Because he believes with his heart he does anything that he thinks true to get freedom for himself and his friends. His self trust is a key to the black freedom.

\section{BIBLIOGRAPHY}

Clark, H.H. 1975. Transition in American Literary History. New York: The Oddisey Press.

Denscombe, M. 2007. The Good Research Guide for Small-Scale Social Research Project. (3rd ed). New York: Open University Press.

Douglass, F. 1981. Narrative of the Life of Frederick Douglass, An American Slave. New York: The New American Library, Inc.

Frenz, H. 1954. Writers of the Western World. Boston: Riberside Press.

Lipset, S.M. 1995. The Encyclopedia of Democracy. Washington: Congressional Quarterly, Inc

Padduck, L. 2000. Encyclopedia of American Literature. The Age of Romanticism and Realism 1815-1914. New York: Fact on File, Inc. 